\title{
SWINE TRICHINELLOSIS IN SLAUGHTERHOUSES OF THE METROPOLITAN AREA OF TOLUCA
}

\author{
MONROY H.*, FLORES-TRUJILLO M.*, BENITEZ E.* \& ARRIAGA C.**
}

\section{Summary :}

In order to determine the prevalence of Trichinella spiralis infections in abattoirs of the metropolitan area of Toluca where pigs from commercial farms as well as backyard pigs are slaughtered, 539 swine diaphragm tissue samples were collected and examined by trichinoscopy and artificial digestion. Serum samples from the same animals were analyzed by ELISA using somatic and excretory/secretory antigens, and by Western blot analysis. T. spiralis muscle larvae were not found by trichinoscopy or artificial digestion. However, specific antibodies were detected by ELISA and confirmed by Western blotting in $12.4 \%$ of the serum samples examined. Analysis of risk factors showed no association of seropositive results with sex. However, significant higher risk was observed in swine seven to 12 months old and in backyard pigs, compared with pigs from commercial farms.

KEY WORDS : Trichinellosis, swine, seroprevalence, risk factors.

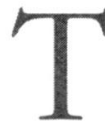
richinellosis is considered endemic in the metropolitan area of Toluca, State of Mexico, where several human cases were documented from 1978 to 1982 and two outbreaks involving 18 persons occurred in 1983. Thirty eight more cases, confirmed by biopsy were reported from 1985 to 1986 and 15 were officially notified from 1992 to 1997 in this area (Martínez-Marañón et al., 1985; González et al., 1991; Ortega-Pierres et al., 2000). In addition, a frequency of $14.8 \%$ of Trichinella infections was determined in human cadavers taken to the Forensic Service in Toluca (González et al., 1991). In all cases, consumption of infected pork meat was considered as the source of infection for humans.

On the other hand, Trichinella spiralis infections in backyard pigs from this area have also been demonstrated both by ELISA and Western blot analysis and by direct detection of the parasite in muscle tissue samples by artificial digestion. In these studies a seroprevalence of $24 \%$ was determined (Arriaga et al., 1989) and muscle larvae $(\mathrm{ML})$ were detected in three of $50(6 \%)$

\footnotetext{
* CIESA FMVZ Universidad Autónoma del Estado de México. Toluca Edo de México. hgms@coatepec.uaemex.mx / mvzhgms@hotmail.com ** CENID-Microbiología, INIFAP, SAGAR, México, D.F.

Correspondence: C. Arriaga.

Tel.: 52-5-5703100 Ext. 30 - Fax: 52-5- 5704073

E-mail: camila@micro.inifap.conacyt.mx
}

pigs examined at slaughter (Arriaga et al., 1991). Nevertheless, data on prevalence of swine trichinellosis in abattoirs of this area is limited. In 1992 the Health Institute of the State of Mexico (ISEM) started a program of Control and Epidemiologic Survaillance of trichinellosis, based on inspection by trichinoscopy at the municipal abattoir of Toluca where pigs from commercial farms as well as backyard pigs are slaughtered. During 1993 and 1994, a total of 151,900 carcasses were examined and in two animals Trichinella ML were detected. Since then, positive animals have not been notified. In this study, in addition to trichinoscopy, artificial digestion and immunoenzymatic techniques were used to determine the prevalence of $T$. spiralis infections in these abattoirs. Association of the presence of specific antibodies against $T$. spiralis with sex, age and type of farm was also investigated.

\section{MATERIAL AND METHODS}

\section{TISSUE AND SERUM SAMPLES}

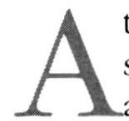
total of 539 swine diaphragm tissue and serum samples were collected. One hundred of the from commercial farms.

\section{ARTIFICIAL DIGESTION AND TRICHINOSCOPY}

Tissue samples $(10 \mathrm{~g})$ were examined by artificial digestion with $1 \%$ pepsine-HCL and trichinoscopy, according to standard procedures.

\section{ANTIGENS}

Somatic (SOM) antigen was prepared as described before (Parkhouse et al., 1981) and excretory/secretory $(\mathrm{E} / \mathrm{S})$ antigens were obtained according to Gamble et al. (1983).

\section{ELISA}

Serum samples were diluted 1:50 and analyzed by ELISA using the method described by Arriaga et al. (1989) with some modifications. Cut off values were 
determined as the average optical density (O.D.) value obtained with serum samples from non infected swine plus two standard deviation. ELISA-positive samples were confirmed by Western blot as described before (Arriaga et al., 1989).

\section{EPIDEMIOLOGIC ANALYSIS}

EPIDAT (APHIS) was used to determine associations between variables and carry out risk analysis by sex, age and type of farm

\section{RESULTS}

T Trichinella ML were not detected by artificial digestion or trichinoscopy in any of the samples examined. However, $13.9 \%(75 / 539)$ of the serum samples were positive in ELISA using SOM and $11.7 \%(63 / 539)$ were positive using $\mathrm{E} / \mathrm{S}$ antigens (Table I). Sixty seven out of 539 (12.4\%) samples, 63 of them positive in ELISA using E/S antigens and four positive in ELISA only with SOM antigen, were confirmed by Western blot analysis since they showed characteristic recognition of TSL-1 antigens. Representative patterns of antigenic recognition by these serum samples are shown in Figure 1. Distribution of seropositive results by sex, age and type of farm is pre-

\begin{tabular}{lccccc}
\hline & Positive & $\mathbf{\%}$ & Negative & \% & Total \\
\hline ELISA-SOM $^{\text {a }}$ & 75 & 13.9 & 464 & 86.1 & 539 \\
ELISA-E/S $^{\mathrm{a}}$ & 63 & 11.7 & 476 & 88.3 & 539 \\
Western Blot & 67 & 12.4 & 472 & 87.6 & 539 \\
\hline
\end{tabular}

${ }^{a}$ Cut off value for ELISA was determined as the average OD value obtained with serum sample from 20 non infected swine plus two standard deviation. This values were 0.5 for ELISA-SOM and 0.6 for ELISA E/S.

Table 1. Percentage of samples positive by ELISA and Western Blot.

sented in Table II. Higher seroprevalence rates were obtained with backyard pigs and with pigs 7-12 months old. Statistical relative risk analysis showed no association with respect to sex. However, higher risk was observed in swine 7-12 months of age (O.R. 6.49) and in backyard pigs (O.R. 2.47) as shown in Table III.

\section{DISCUSSION}

I n this study, a seroprevalence of trichinellosis of $12 \%$ was determined in swine slaughtered in the 1 area of Toluca, although no Trichinella ML could be detected in these animals either by trichinoscopy or artificial digestion. Although cross reactivity with

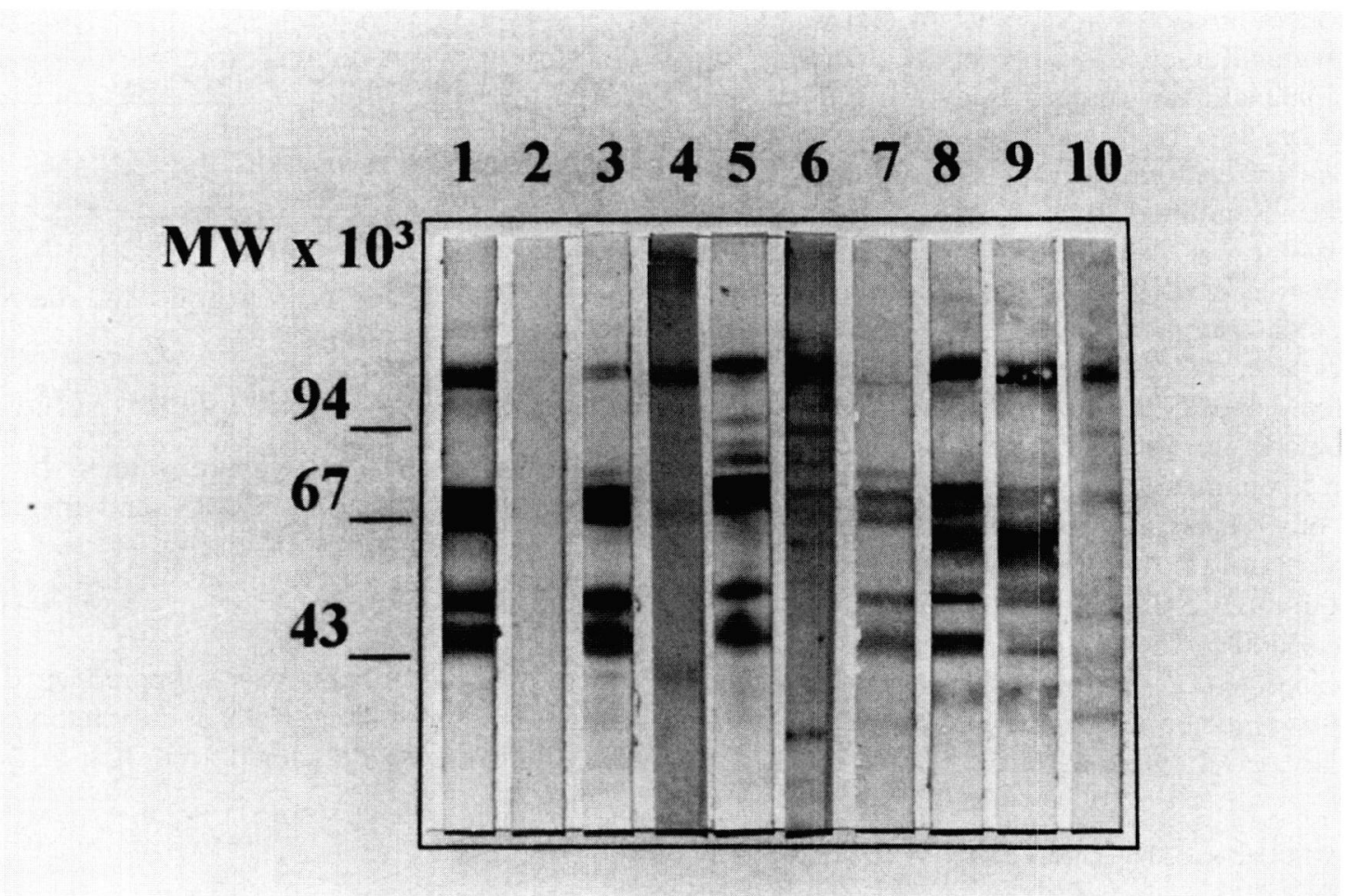

Fig. 1. - Representative patterns of antigenic recognition obtained by Western blot analysis with serum samples from slaughtered pigs. Lane 1: serum sample from experimentally infected swine. Lane 2: serum sample from non infected control. Lanes 3-10: serum samples positive in ELISA using $\mathrm{E} / \mathrm{S}$ antigens. 


\begin{tabular}{lcccc}
\hline Sex & Sample & $\mathbf{\%}$ & Positive & Rate (x 100) \\
\hline Male & 282 & 54.5 & 37 & 0.13 \\
Female & 257 & 45.5 & 30 & 0.11 \\
Total & 539 & 100.0 & 67 & - \\
\hline Age (months) & Sample & $\mathbf{\%}$ & Positive & Rate (x 100) \\
\hline $0-6$ & 232 & 43.0 & 26 & 0.11 \\
$7-12$ & 178 & 33.0 & 37 & 0.20 \\
$13-24$ & 103 & 19.1 & 4 & 0.04 \\
$>25$ & 26 & 4.9 & 0 & 0.0 \\
Total & 539 & 100.0 & 67 & - \\
\hline Farm type & Sample & $\mathbf{\%}$ & Positive & Rate (x 100) \\
\hline Backyard & 100 & 18.6 & 22 & 0.22 \\
Commercial & 439 & 81.4 & 45 & 0.10 \\
Total & 539 & 100.0 & 67 & -
\end{tabular}

Table II. - Epidemiological Analysis of Western blot results.

\begin{tabular}{|c|c|c|c|}
\hline Sex & $\begin{array}{c}\text { Odds Ratio } \\
\text { Confidence } \\
\text { Interval }\end{array}$ & $\begin{array}{c}\text { Risk Ratio } \\
\text { Confidence } \\
\text { Interval }\end{array}$ & $\chi^{2}$ \\
\hline Male & $\begin{array}{c}1.14 \\
0.66<\mathrm{OR}<1.97\end{array}$ & $\begin{array}{c}1.12 \\
0.72<R R<1.76\end{array}$ & 0.26 \\
\hline Female & 1.0 & 1.0 & \\
\hline Age (months) & $\begin{array}{c}\text { Odds Ratio } \\
\text { Confidence } \\
\text { Interval }\end{array}$ & $\begin{array}{c}\text { Risk Ratio } \\
\text { Confidence } \\
\text { Interval }\end{array}$ & $\chi^{2}$ \\
\hline $0-6$ & $\begin{array}{c}3.12 \\
1.00<\mathrm{OR}<10.87\end{array}$ & $\begin{array}{c}2.89 \\
1.03<R R<8.06\end{array}$ & 4.69 \\
\hline $7-12$ & $\begin{array}{c}6.49 \\
2.12<\mathrm{OR}<22.2\end{array}$ & $\begin{array}{c}5.35 \\
1.96<R R<14.6\end{array}$ & 14.96 \\
\hline $13-24$ & 1.0 & 1.0 & - \\
\hline Farm type & $\begin{array}{c}\text { Odds Ratio } \\
\text { Confidence } \\
\text { Interval }\end{array}$ & $\begin{array}{c}\text { Risk Ratio } \\
\text { Confidence } \\
\text { Interval }\end{array}$ & $\chi^{2}$ \\
\hline Backyard & $\begin{array}{c}2.47 \\
1.35<\mathrm{OR}<4.5\end{array}$ & $\begin{array}{c}2.15 \\
1.35<\mathrm{RR}<3.4\end{array}$ & 10.33 \\
\hline Commercial & 1.0 & 1.0 & - \\
\hline
\end{tabular}

$\mathrm{P}<0.05$.

Confidence level $95 \%$.

Table III. - Risk Analysis of Western blot results.

other nematodes or bacteria infecting swine could explain some of the positive results obtained in ELISA using crude extracts of the parasite, the use of $\mathrm{E} / \mathrm{S}$ antigens greatly improves the specificity of the test (Gamble et al., 1983; Arriaga et al., 1989). Besides, the fact that serum samples positive in ELISA using E/S showed reactivity mainly with TSL-1 antigens suggests that these are specific reactions. These results are in accordance with the high percentage of seropositive backyard pigs that has been previously determined in this region (Arriaga et al., 1989). Furthermore, the seroprevalence found in this area agrees with the frequency of $14.8 \%$ that has been reported in human cadavers (González et al., 1991). Failure to detect ML by artificial digestion could probably be explained by low parasite burdens, below the limit of detection of this technique. In this case, recovery of ML could be improved by increasing the sample size.

As expected, the percentage of seropositive animals was higher among backyard pigs than in swine from commercial farms and stresses the need of adequate farming conditions for the control of trichinellosis. The finding of higher risk in swine in the age group of 712 months was interesting since these were animals that for different reasons did not gain weight, thus took longer to be ready for the slaughterhouse. Association of trichinellosis with other diseases could probably explain this finding and should be investigated.

\section{REFERENCES}

Arriaga C., Muñiz E., Morilla A. \& Ortega-Pierres G. Trichinella spiralis: Recognition of muscle larva antigens during experimental infection of swine and its potential use in diagnosis. Experimental Parasitology, 1989, 69, 363-372.

arriaga C., Salinas-Tobón R., Morilla A. \& Ortega-Pierres G. Use of purified surface-stichosomal antigens of Trichinella spiralis muscle larva in the detection of naturally infected swine. Research and Reviews in Parasitology, 1991, 51, 103105 .

Gamble H.R., Anderson W.R., Graham C.E. \& Murrell K.D. Diagnosis of swine trichinosis by enzyme-linked immunosorbent assay (ELISA) using an excretory-secretory antigen. Veterinary Parasitology, 1983, 13, 349- 361.

González H.L., Pérez V.O., Ramirez A.J. \& Ruano C.J. Frecuencia de la infección por Trichinella spiralis en diafragmas de cadáveres humanos. Gaceta Médica del Instituto de Salud del Estado de México, 1991, 1, 66-72.

Martinez-Marañon R. Está aumentando la triquinosis en México? Podría ser esto una consecuencia inesperada de nuestro "desarrollo" ? Salud Pública de México, 1985, 27, 40-51.

Ortega-Pierres M.G., Arriaga C. \& Yépez-Mulia L. Trichinellosis in Mexico, Central and South America. Veterinary Parasitology, 2000, 93, 201-225.

PARKhouse R.M.F., Philipp M. \& OGILvie B.M. Characterization of surface antigens of Trichinella spiralis infective larvae. Parasite Immunology, 1981, 3, 339-352. 